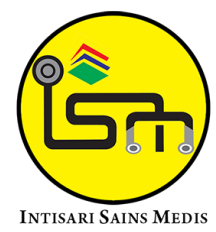

Published by Intisari Sains Medis

\title{
Peran vitamin B6 terhadap inflamasi pada adhesi peritoneal pasca laparotomi: tinjauan pustaka
}

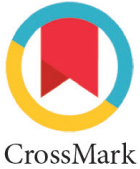

\author{
Made Agus Dwianthara Sueta ${ }^{1 *}$, I Dewa Made Sukrama²
}

\section{ABSTRACT}

Vitamin B6 or pyridoxine has been shown to modulate hypoxia and inflammation, but it has not yet confirmed their local effects on the peritoneum. Although there was no study regarding this issue, pyridoxine effects on suppressing these two pathways look promising as a preventing agent against peritoneal adhesion. The development of intraperitoneal adhesion postoperation is one of the most common complications after abdominal surgery. Approximately $95 \%$ of patients who underwent laparotomy can develop adhesions in the future. Pathogenesis of adhesion consists of three important processes which were induced by trauma: trauma or direct tissue injuryinduced suppression of degradation of fibrinolytic matrix and extracellular system, inflammation response with cytokine production, particularly TGF- $\beta$ and interleukin, also tissue hypoxia as the impact from circulation disorder toward mesothelial cell and submesothelial fibroblasts, which results as increasing hypoxia-inducible factor-alpha (HIF-1a) and vascular endothelial growth factor (VEGF), which are responsible for generating collagen and angiogenesis process. Pyridoxine has biological activity and interesting characteristics in avoiding intra-peritoneal adhesion by dealing with inflammation effects and hypoxia. From the inflammation process, pyridoxine has been shown can hinder macrophage, decrease IL-6, suppress TLR-mediated TAK1 phosphorylation, JNK, IKK-IKBa, which can cause a reduction in NF- $K B$ activation and NLRP3-mediated caspase-1, also suppress iNOS and cyclooxygenase-2 (COX2), which contributed to developing intra-peritoneal adhesion.

Keywords: Vitamin B6, Pyridoxine, Peritoneal Adhesion, Inflammation.

Cite This Article: Sueta, M.A.D., Sukrama, I.D.M. 2021. Peran vitamin B6 terhadap inflamasi pada adhesi peritoneal pasca laparotomi: tinjauan pustaka. Intisari Sains Medis 12(3): 699-705. D0I: 10.15562/ism.v12i3.1105

\section{ABSTRAK}

Vitamin B6 (Vit B6), atau piridoksin telah ditunjukkan dapat memodulasi efek hipoksia dan inflamasi, tetapi belum dikonfirmasi efek lokalnya pada peritoneum. Walaupun belum ada penelitian langsung, efek supresi vitamin B6 terhadap kedua jalur tersebut sangat menjanjikan sebagai agen prevensi adhesi peritoneal. Perkembangan adhesi intraperitoneal pasca operasi adalah salah satu komplikasi paling umum setelah operasi abdominal. Sekitar 95\% pasien yang menjalani laparotomi akan mengalami perlengketan di kemudian hari. Patogenesis adhesi melibatkan tiga proses penting yang diinduksi trauma: trauma atau kerusakan jaringan langsung menginduksi penghambatan sistem degradasi matriks fibrinolitik dan ekstraseluler, respons inflamasi dengan produksi sitokin, terutama TGF- $\beta$ dan interleukin, serta hipoksia jaringan sebagai akibat dari gangguan suplai darah ke sel mesothelial dan fibroblas submesothelial, yang mengarah pada peningkatan hypoxia inducible factor-alpha (HIF-1a) dan faktor pertumbuhan endotel vaskular (VEGF), yang bertanggung jawab untuk pembentukan kolagen dan angiogenesis. Vitamin B6 menyajikan sifat dan aktivitas biologis yang menarik untuk mencegah adhesi intraperitoneal dengan mengatasi efek inflamasi dan hipoksia. Pada jalur inflamasi, vitamin B6 terbukti menghambat makrofag, menurunkan IL-6, menghambat fosforilasi TLR-mediated TAK1, JNK, serta IKK-IKBa, yang menyebabkan penurunan aktivasi NF-KB and NLRP3mediated caspase-1, serta menghambat iNOS dan cyclooxygenase-2 (COX2) yang berkontribusi terhadap pembentukkan adhesi intraperitoneal.

Kata kunci: Vitamin B6, Adhesi Peritoneal, Inflamasi.

Sitasi Artikel ini: Sueta, M.A.D., Sukrama, I.D.M. 2021. Peran vitamin B6 terhadap inflamasi pada adhesi peritoneal pasca laparotomi: tinjauan pustaka. Intisari Sains Medis 12(3): 699-705. D0I: 10.15562/ism.v12i3.1105 


\section{PENDAHULUAN}

Adhesi adalah komplikasi paling sering dari operasi abdominopelvik, berkorelasi dengan tingkat morbiditas dan mortalitas yang tinggi. ${ }^{1}$ Pengembangan adhesi setelah setiap proses bedah dipengaruhi oleh berbagai faktor, seperti, kompleksitas operasi, luasnya trauma peritoneum, penyakit sebelumnya, dan status gizi yang buruk. ${ }^{1}$ Penelitian tentang metode yang efektif untuk pencegahan adhesi, telah mengusulkan berbagai teknik dan agen farmakologis yang berguna baik untuk pencegahan primer maupun sekunder.

Vitamin B6 (Vit B6), atau piridoksin, adalah senyawa yang sangat penting untuk metabolisme seluler umum. $^{2}$ Vitamin B6 telah ditunjukkan dapat memodulasi efek hipoksia dan inflamasi, tetapi belum dikonfirmasi efek lokalnya pada peritoneum. ${ }^{3}$ Walaupun belum ada penelitian langsung, efek supresi vitamin B6 terhadap ketiga jalur tersebut sangat menjanjikan sebagai agen prevensi adhesi peritoneal.

Berkaitan dengan hal tersebut maka penulisan tinjauan kepustakaan ini mencoba untuk menjelaskan peran vitamin B6 atau piridoksin terhadap inflamasi pada adhesi peritoneal pasca laparotomi.

\section{MORFOLOGI ADHESI INTRAPERITONEAL}

Adhesi peritoneal adalah ikatan fibrin patologis yang biasanya terjadi antara omentum, loop usus, dan dinding perut. Ikatan ini dapat berupa lapisan tipis jaringan ikat, jembatan fibrosa tebal yang berisi pembuluh darah dan jaringan saraf, atau jaringan tipis yang kontak langsung antara dua permukaan organ. ${ }^{4}$ Menurut etiologi, adhesi peritoneal dapat diklasifikasikan sebagai bawaan atau didapat, yang dapat terjadi pasca inflamasi atau pasca operasi. ${ }^{4} \mathrm{Di}$ antara pembentukan adhesi pasca operasi, tiga proses yang ada yaitu: pembentukan adhesi (adhesi terbentuk di tempat operasi); pembentukan adhesi de novo (adhesi yang terbentuk di tempat nonoperasi); dan reformasi adhesi (adhesi yang terbentuk setelah lisis dari adhesi sebelumnya). ${ }^{4}$ Studi yang dilakukan oleh

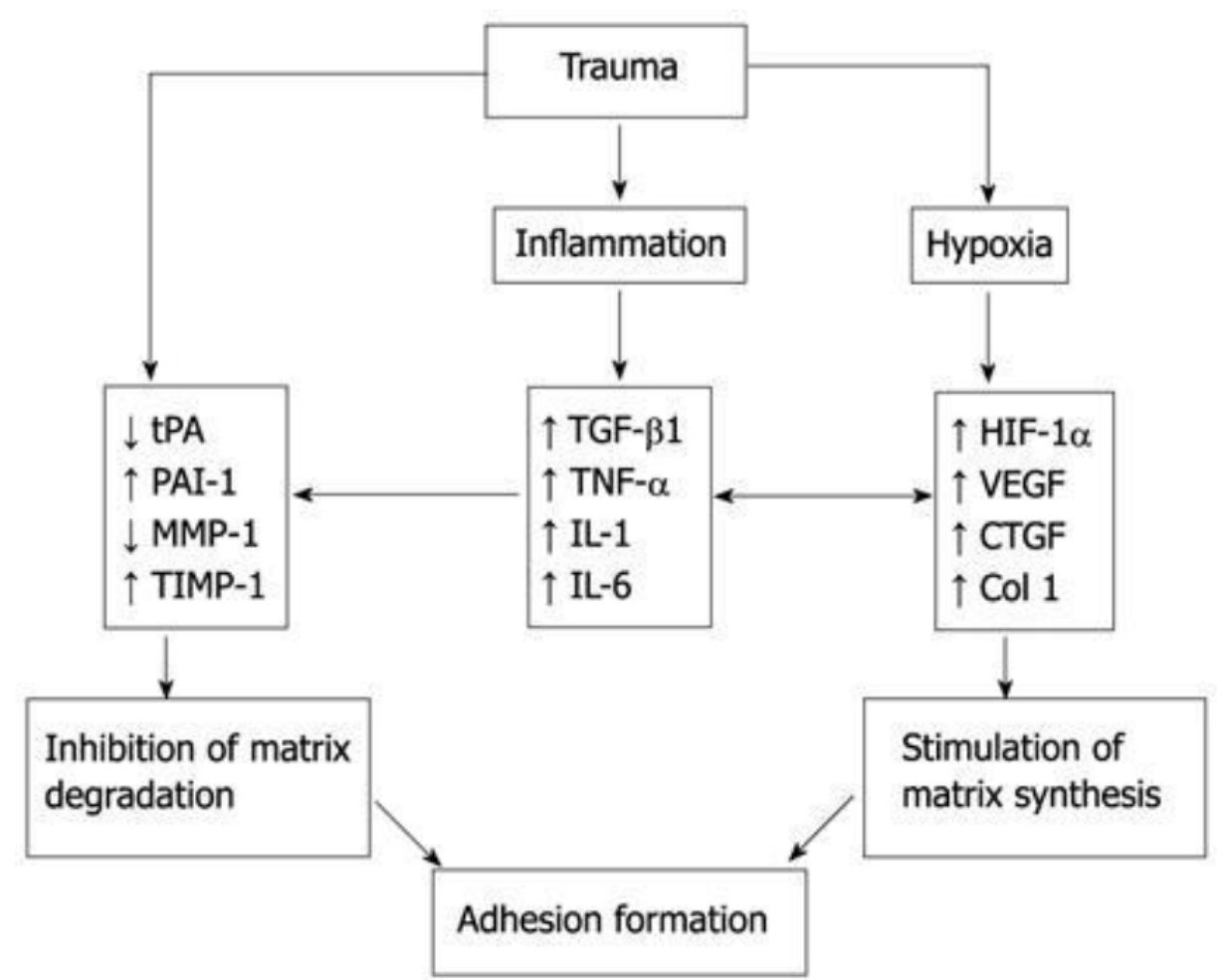

Gambar 1. Patofisiologi adhesi intraperitoneal. ${ }^{8}$

Diamond MP et al., membedakan tipe 1 dan tipe 2 dari adhesi peritoneal pasca operasi. ${ }^{5}$ Tipe 1 atau pembentukan adhesi de novo berkaitan dengan adhesi yang terbentuk di lokasi yang tidak memiliki perekatan sebelumnya, termasuk tipe $1 \mathrm{~A}$ (tidak ada prosedur operasi sebelumnya di lokasi adhesi) dan tipe 1B (prosedur operasi sebelumnya di lokasi adhesi). Tipe 2 melibatkan reformasi adhesi dengan dua subtipe diantaranya tipe 2A (tidak ada prosedur operasi di lokasi adhesi selain adhesiolisis) dan tipe 2B (prosedur operasi lain di lokasi adhesi selain adhesiolisis).

Adhesi peritoneal sebagian besar disebabkan oleh prosedur pembedahan dengan prevalensi sebanyak $63 \%-97 \%{ }^{6}$ Secara keseluruhan, sekitar sepertiga dari pasien yang menjalani operasi perut terbuka dirawat kembali rata-rata dua kali selama 10 tahun berikutnya untuk kondisi yang secara langsung atau mungkin terkait dengan adhesi, atau untuk operasi lebih lanjut yang berpotensi dipersulit oleh adhesi dimana $>20 \%$ terjadi selama tahun pertama setelah operasi awal dan 4,5\% terjadi akibat obstruksi usus halus.?

\section{PATOGENESIS ADHESI INTRAPERITONEAL}

Patogenesis adhesi melibatkan tiga proses penting yang diinduksi trauma: trauma atau kerusakan jaringan langsung menginduksi penghambatan sistem degradasi matriks fibrinolitik dan ekstraseluler, respons inflamasi dengan produksi sitokin, terutama Transforming Growth Factor- $\beta$ (TGF- $\beta$ ) dan interleukin, serta hipoksia jaringan sebagai akibat dari gangguan suplai darah ke sel mesothelial dan fibroblas submesothelial, yang mengarah pada peningkatan hypoxia inducible factor-alpha (HIF-1a) dan Vascular Endothelial Growth Factor (VEGF), yang bertanggung jawab untuk pembentukan kolagen dan angiogenesis (Gambar 1).

Segera setelah cedera, ditemukan ada perdarahan dan peningkatan permeabilitas pembuluh darah dengan kebocoran cairan dari permukaan yang terluka. ${ }^{9}$ Secara bersamaan, respon inflamasi post traumatik terjadi, dengan infiltrasi sel inflamasi, pelepasan sitokin proinflamasi dan aktivasi kaskade komplemen dan 


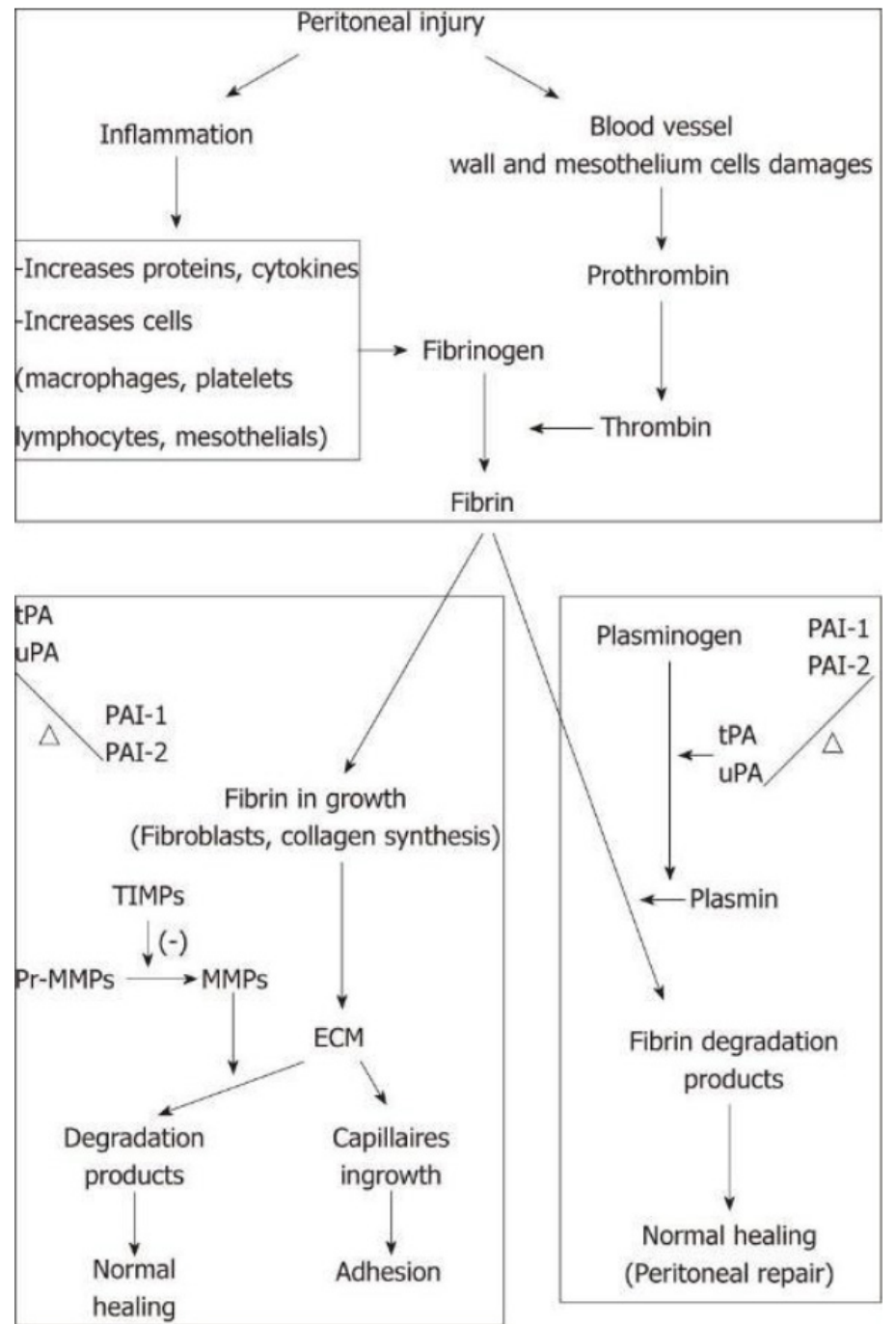

Gambar 2. Mekanisme inflamasi pada adhesi intraperitoneal. ${ }^{10}$

koagulasi. Eksudat juga mengandung substrat seperti fibronektin, asam hialuronat, berbagai glikosaminoglikan (GAG), dan proteoglikan yang berperan dalam proses penyembuhan luka (Gambar 2).

Setelah trauma, sel-sel inflamasi awal sebagian besar yang direkrut adalah neutrofil, dengan sebagian besar perubahan menjadi makrofag pada 24 jam. Makrofag peritoneal khususnya telah terlibat dalam respon imun yang memicu pembentukan adhesi. ${ }^{11}$ Diketahui bahwa sitokin spesifik dan faktor pertumbuhan bertanggung jawab untuk meningkatkan regulasi gen yang produknya dapat membantu memulai pembentukan adhesi. Contohnya termasuk gen untuk Neurokinin-1 (NK-1) reseptor, mengubah TGF- $\beta$, zat $\mathrm{P}$ (SP), molekul
Intracellular Adhesion Molecule-1 (ICAM1) dan Vascular Cell Adhesion Molecule-1 (VCAM-1). Peningkatan kadar mRNA yang ditranskripsi dari masing-masing gen ini telah ditemukan dalam jaringan peritoneum tikus awal setelah trauma pembedahan. ${ }^{12}$

TGF- $\beta$ adalah sitokin sekaligus dan faktor pertumbuhan kuat yang menginisiasi, memodulasi dan mengakhiri perbaikan jaringan. Baik TGF- $\beta$ dan reseptornya meningkat pada jaringan peritoneum dan cairan setelah operasi transperitoneal. Studi in vitro menunjukkan bahwa TGF- $\beta$ berkontribusi terhadap penurunan kapasitas fibrinolitik peritoneum dan mungkin memiliki peran dalam mencegah degradasi awal adhesi fibrin. ${ }^{13}$ Bukti in vivo menunjukkan hewan menerima TGF- $\beta$ pada laparotomi memiliki adhesi lebih signifikan daripada kelompok kontrol ketika diperiksa ulang beberapa hari kemudian. ${ }^{13,14}$ Mekanisme pasti TGF- $\beta$ dalam memediasi respons ini tidak diketahui. Namun, studi awal menunjukkan bahwa itu mungkin melibatkan regulasi PAI- $1 .^{13}$ TGF- $\beta 1$ dikaitkan dengan pengurangan tPA dan peningkatan pelepasan PAI-1. ${ }^{14}$

Peran interleukin-1 (IL-1) dalam patofisiologi pembentukan adhesi juga banyak diteliti. ${ }^{13}$ Studi telah menunjukkan bahwa, selain mempromosikan peradangan dan koagulasi primer, IL-1 juga berkontribusi terhadap penurunan keseluruhan kapasitas fibrinolitik lokal dalam pembentukan adhesi. Peningkatan kadar IL-1 $\beta$ dalam cairan peritoneum pasca operasi berkorelasi dengan adhesi intraperitoneal. Secara in vivo, IL-1 $\beta$ telah ditemukan dapat menstimulasi pelepasan PAI-1 dalam sel mesothelial sehingga berperan dalam menghambat degradasi fibrin lokal. ${ }^{13}$

Interleukin-6, interleukin-8 dan interleukin-10 berpartisipasi dalam modulasi respon seluler akibat trauma peritoneal, namun perannya masih belum jelas. ${ }^{13}$ Sel-sel mesotelial adalah sel-sel yang berperan dalam sekresi IL-6 utama dalam rongga peritoneum. Trauma memicu sel ini menghasilkan sitokin dalam jumlah besar. Dalam model tikus, ditemukan bahan kadar IL-6 yang tinggi berkorelasi erat dengan kejadian adhesi intraperitoneal yang lebih tinggi dibandingkan kontrol. ${ }^{13}$

Pada keadaan inflamasi, terjadi peningkatan faktor pertumbuhan, kemokin, sitokin, dan keseimbangan ROS yang mengakibatkan mutasi gen. ${ }^{15}$ Keadaan proinflamasi yang akan membentuk banyak radikal bebas sehingga menimbulkan keadaan hipoksia. Pada keadaan hipoksia kadar ROS akan meningkat. Beberapa ROS seperti O2, $\mathrm{H} 2 \mathrm{O} 2$, OH- yang dihasilkan selama metabolisme aerobik normal diketahui berperan sebagai molekul sinyal yang menginduksi berbagai proses biologis, seperti stimulasi protein fosforilasi, $\mathrm{Ca} 2+-$ signaling, hidrolisis fosfolipid, dan aktivasi faktor transkripsi. Pada keadaan hipoksia juga terjadi peningkatan kadar reactive oxygen species (ROS). ${ }^{15}$

Hipoksia menginduksi inflamasi 


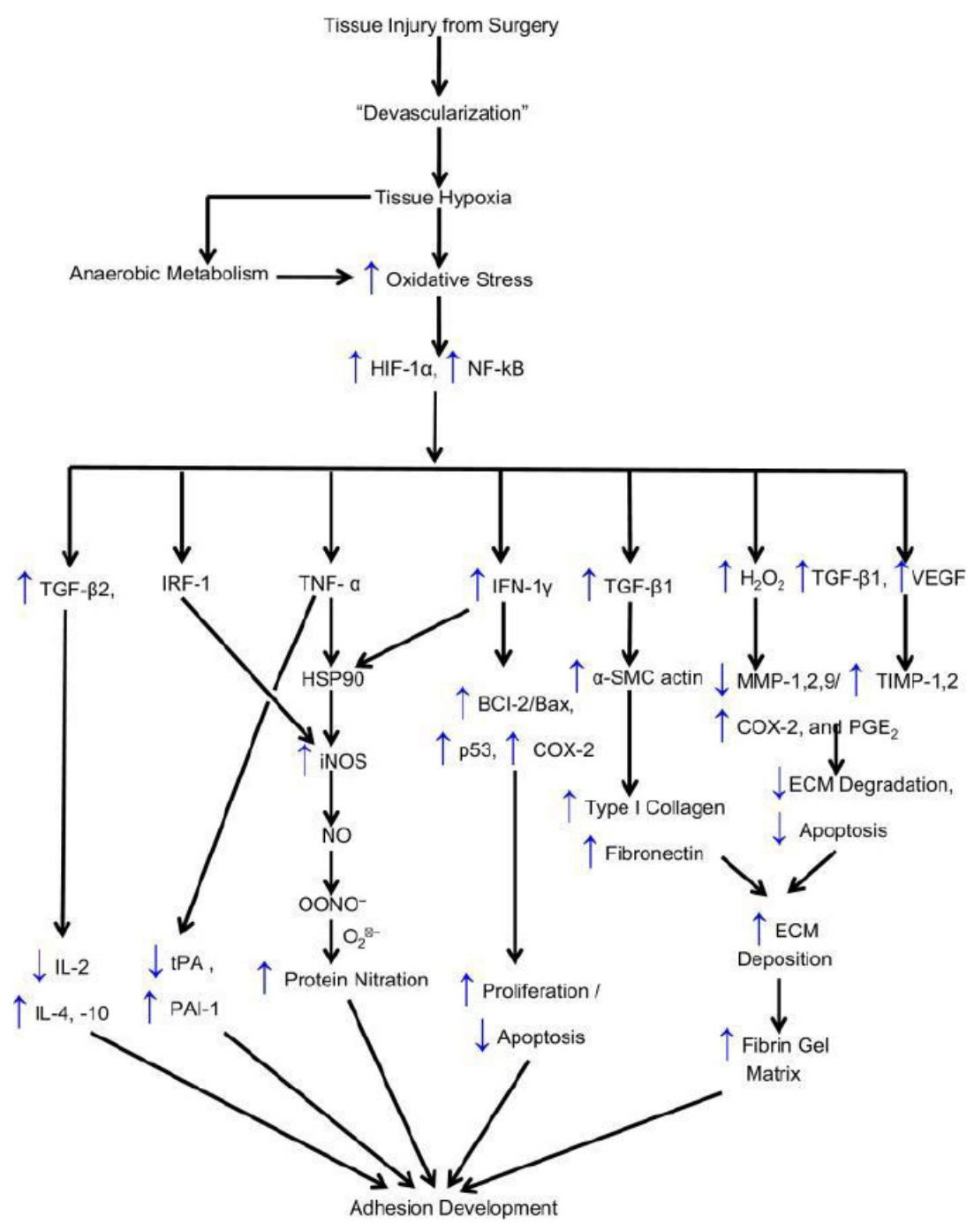

Gambar 3. Mekanisme hipoksia pada adhesi intraperitoneal. ${ }^{18}$

melalui pelepasan mediator-mediator inflamasi oleh sel parenkim maupun endotel yang hipoksik. Neutrofil sebagai salah satu efektor inflamasi akut bekerja dengan membangkitkan radikal bebas. ${ }^{16}$ Kompleks faktor transkripsi yang diinduksi hipoksia, Hypoxia Inducible Factor-1 (HIF-1) diatur oleh hipoksia juga oleh berbagai macam mediator inflamasi. Setelah extravasasi dari pembuluh darah tersebut, aktivitas sel lebih ditingkatkan dengan stimulasi HIF-1 oleh sitokin proinflamasi seperti IL-1, IL-6, TNF-alfa, dan faktor jaringan yang diekspresikan secara lokal. ${ }^{16}$ TNF- $\alpha$ yang disebabkan stimulasi HIF-1 1 stimulasi membutuhkan NF-kB pada tingkat stabilisasi protein HIF-1a tanpa mempengaruhi tingkat mRNA-nya. ${ }^{16}$

Dalam kondisi fisiologis normal, sel eukariotik berada dalam kondisi aerob dan memiliki sistem pertahanan bawaan terhadap ROS yang berkontribusi pada pemeliharaan keseimbangan antara prooksidan dan kemampuan antioksidan. Dalam kondisi hipoksia, rantai pernapasan mitokondria menghasilkan nitrat oksida (NO) yang dapat menghasilkan spesies nitrogen reaktif (RNS; ONOO-, nitrit [NO2 -], nitrat [NO3 -]), yang selanjutnya menghasilkan spesies reaktif lainnya seperti aldehida reaktif-Malondialdehyde dan 4-hydroxynonena- yang dapat menyerang membran lipid untuk memulai reaksi berantai radikal bebas yang dikenal sebagai peroksidasi lipid. ${ }^{17} \mathrm{Di}$ tingkat molekular, hipoksia menurunkan Tissue Plasminogen Activator (tPA) dan meningkatkan ekspresi PAI pada fibroblas peritoneum manusia secara in vitro dan pada jaringan peritoneum in vivo, sehingga mengurangi plasmin, menghambat lisis fibrin, dan meningkatkan pembentukan adhesi (Gambar 3). ${ }^{17}$

Eksudat cairan yang dilepaskan dari permukaan peritoneum yang mengalami trauma kaya akan protein plasma, terutama fibrinogen. Aktivasi kaskade koagulasi memicu pembentukan fibrinol, yang diperlukan untuk konversi fibrinogen menjadi fibrin. Kandungan fibroblas meningkat pada minggu kedua pasca trauma, diikuti oleh pembentukan struktur pembuluh dan elemen jaringan ikat. ${ }^{18,19}$

Kemudian mulai 72 jam setelah trauma, pembentukan fibrin dari fibroblas akan diseimbangkan oleh degradasi lapisan fibrin oleh protease yang dilepaskan secara lokal dari sistem fibrinolitik. ${ }^{20}$ Fibrinolisis memungkinkan sel mesotelial untuk berproliferasi dan trauma peritoneal untuk pulih dalam waktu 4 hingga 5 hari, serta mencegah perlekatan permanen pada permukaan yang berdekatan. ${ }^{21}$ Jika fibrinolisis tidak terjadi dalam 5 hingga 7 hari dari cedera peritoneum, atau jika aktivitas fibrinolitik lokal berkurang, matriks fibrin tetap ada. ${ }^{13}$ Jika ini terjadi, matriks fibrin sementara secara bertahap menjadi lebih terorganisir sebagai fibroblast yang mensekresi kolagen dan fibrin matur patologis. ${ }^{20}$ Fibrinogen inaktif pada jaringan intraperitoneal adhesi akan tertimbun menjadi matriks gel fibrin yang tebal dan melekat jaringan satu dengan lainnya. Pada proses adhesi/pembentukan fibrin yang normal, koneksi fibrin ini akan lisis sendiri dalam waktu beberapa hari oleh sistem fibrinolitik. ${ }^{22}$

Ada 2 aktivator utama dalam sistem fibrinolitik yaitu tPA dan aktivator plasminogen seperti urokinase (uPA). Dari keduanya, tPA berperan paling penting dalam penyembuhan luka peritoneal karena memiliki afinitas spesifik untuk fibrin. Ada juga kelompok glikoprotein yang bertindak sebagai inhibitor fibrinolisis dan secara kolektif disebut sebagai Plasminogen Activator Inhibitor (PAI). ${ }^{23}$

Studi sebelumnya menunjukkan bahwa jaringan serosa organ intraperitoneal yang diperoleh selama operasi terbuka mengekspresikan lebih banyak penghambat jaringan metalloproteinase-1 


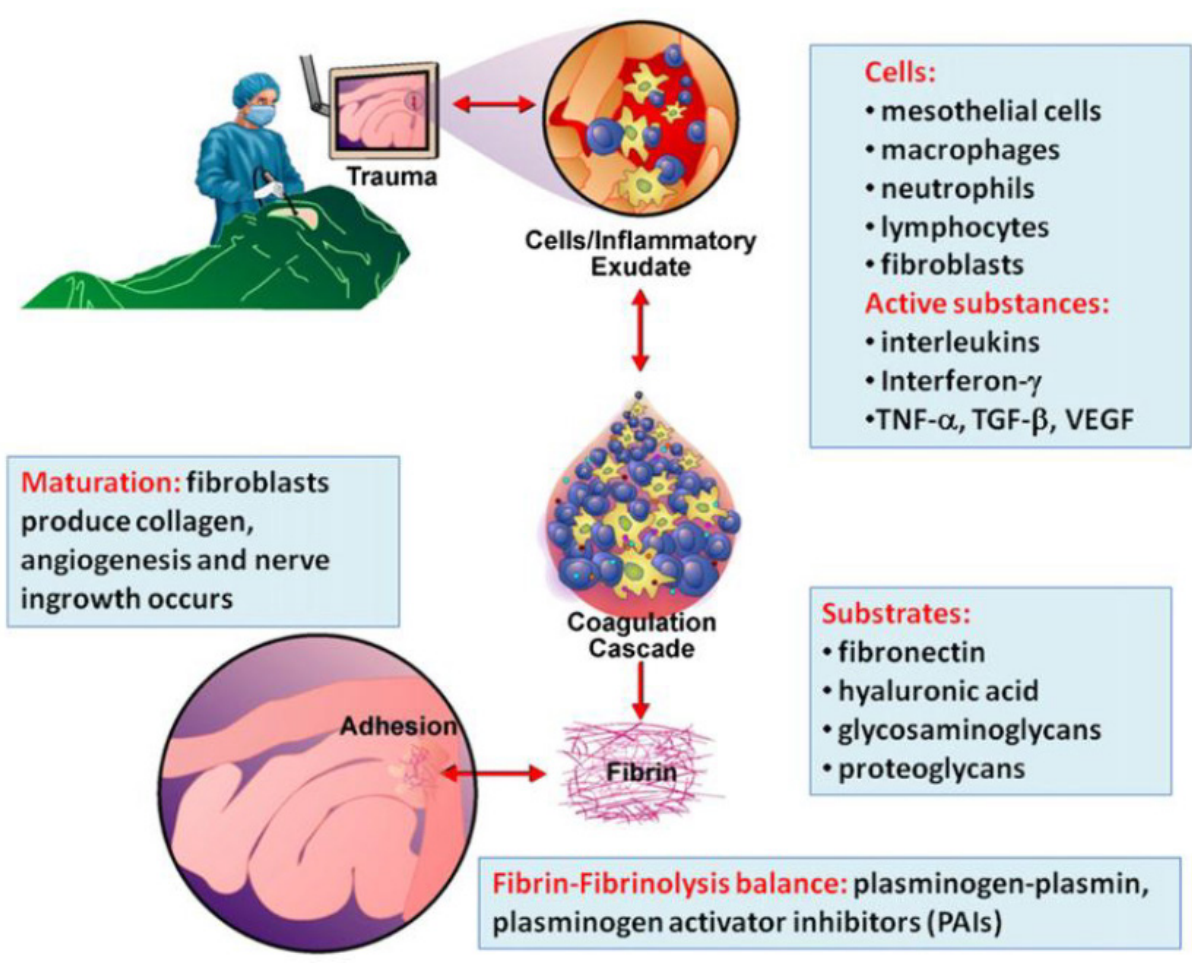

Gambar 4. Mekanisme fibrinolisis pada adhesi intraperitoneal. ${ }^{24}$

(TIMP-1) daripada matriks metalloproteinase-1 (MMP-1). ${ }^{14} \quad$ Pada kasus terjadinya adhesi intraperitoneal, ditunjukkan menunjukkan peningkatan lebih tinggi lagi kadar TIMP-1 dan yang lebih rendah rasio MMP-1 ke TIMP-1 dibandingkan dengan peritoneum parietal yang utuh. ${ }^{14}$

\section{VITAMIN B6}

Vitamin B6 atau piridoksin, adalah senyawa yang sangat penting untuk metabolisme seluler umum. Vitamin B6 diserap dari saluran pencernaan terutama sebagai piridoksin dan diekskresikan dalam urin sebagai asam piridoksin. Koenzim vitamin B6 berpartisipasi dalam lebih dari 100 reaksi yang dikatalisis oleh enzim yang berbeda, yang sebagian besar terjadi di semua sel hidup, dan beberapa di antaranya hanya ada dalam sel hati dan ginjal (situs utama glukoneogenesis). Mereka terlibat dengan glikogenolisis otot, dan dengan metabolisme asam amino, di mana mereka berfungsi dalam berbagai transaminasi, dekarboksilasi, dan dehidratase. $^{3}$

Vitamin B6 diabsorpsi terutama di jejunum dan ileum, melalui mekanisme defosforilasi membrane-bound alkaline phosphatases, kemudian diabsorpsi melalui mekanisme difusi pasif. ${ }^{25}$ Metabolit ini akan difosforilasi ulang di eritrosit menghasilkan perangkap metabolik vitamin dengan oksidasi lebih lanjut menjadi piridoksal-5-fosfat (P-5-P), bentuk aktif metaboliknya. Metabolit terakhir ini harus terdefosforilasi lagi di permukaan serosa usus sebelum dilepaskan ke sirkulasi portal. Piridoksal yang dilepaskan ke sirkulasi portal diserap di hati dengan difusi pasif, diikuti oleh fosforilasi ulang di dalam sel. Untuk melintasi membran sel hati, P-5-P dihidrolisis menjadi piridoksal dan dilepaskan ke sirkulasi umum yang terikat pada albumin dan/atau hemoglobin. ${ }^{25}$

Pentingnya jalur de novo vitamin B6 ditekankan oleh berbagai penelitian di E. coli, Streptococcus pneumonia, Bacillus subtilis, ragi, dan tanaman di mana kehilangan totalnya mematikan bagi organisme, tetapi dapat diselamatkan oleh pasokan vitamin eksogen. Fungsi vitamin B6 antara lain: ${ }^{25}$

1. Keterlibatan dalam folding protein

Keterlibatan ini juga dilaporkan berperan sebagai pendamping dalam pelipatan enzim PLP. Misalnya, aspartat aminotransferase dalam E. coli membutuhkan PLP untuk stabilisasi yang tepat dalam struktur asli, dan ketika protein dipisahkan menjadi sebagian dilipat intermediate, PLP direduksi menjadi turunan pyridol lysine (PPL) untuk 'mengunci' faktor pendamping di tempat. untuk lebih menstabilkan protein. ${ }^{25}$

2. Keterlibatan dalam Biosintesis Asam Amino

Fungsi terpenting dari vitamin B6 aktif, adalah kofaktor fosforilasi dalam sel serta degradasi asam amino. Vitamin digunakan untuk reaksi transaminasi dengan membentuk asam amino-PLP Schiff base intermediate, di mana kelompok amino ditransfer ke asam keto untuk membentuk asam amino baru. Selain itu, vitamin B6 juga digunakan untuk jenis reaksi lain seperti $\alpha$-dekarboksilasi atau rasisasi. ${ }^{3}$ Di hati mamalia, PLP terikat erat dengan albumin serum sebagai basa Schiff sebelum disekresikan ke dalam sistem peredaran darah untuk pengiriman ke berbagai jaringan dan organ..$^{25}$

3. Degradasi Senyawa Penyimpanan Seluler

Glikogen dan pati adalah dua senyawa penyimpanan utama pada hewan, jamur, bakteri, dan tanaman. Pati adalah bentuk penyimpanan karbohidrat utama dalam plastid, dan juga dibangun oleh ikatan $\alpha-1,4-$ dan a-1,6-glikosidik. Glikogen dapat dibuat dapat diakses oleh sel dengan glikogen atau pati fosforilase, enzim yang bergantung pada PLP yang menghidrolisis ikatan $\alpha$-1,4-glikosidik untuk menghasilkan glukosa-1-fosfat. Pada mamalia, glikogen fosforilase ditemukan terutama di hati, otot, dan otak. $^{25}$

4. Biosintesis Neurotransmitter

Survei epidemiologis menemukan bahwa asupan makanan yang mengandung vitamin B6 dalam jumlah besar berkorelasi dengan kesehatan mental yang lebih baik. Ini mungkin terkait dengan fakta bahwa enzim yang bergantung pada vitamin B6 diperlukan untuk biosintesis setidaknya tiga neurotransmitter penting; epinefrin (juga dikenal sebagai adrenalin), 
dopamin (dihydroxyphenethylamine), dan serotonin. ${ }^{25}$

\section{VITAMIN B6 DAN ADHESI PERITONEAL}

Perkembangan adhesi intraperitoneal pasca operasi adalah salah satu komplikasi paling umum setelah operasi abdominal. Sekitar 95\% pasien yang menjalani laparotomi akan mengalami perlengketan di kemudian hari. ${ }^{26}$

Vitamin B6 menyajikan sifat dan aktivitas biologis yang menarik untuk mencegah adhesi intraperitoneal dengan mengatasi efek inflamasi dan hipoksia, sedangkan efek langsung vitamin B6 pada fibrinolisis belum pernah diteliti.

\section{Efek anti-inflamasi}

Pada jalur inflamasi, vitamin B6 terbukti menghambat makrofag yang telah lama dianggap sebagai sel-sel efektor imun yang kuat dengan peran yang sudah mapan baik dalam homeostasis jaringan maupun cedera. ${ }^{27}$ Studi yang dilakukan oleh Ehmedah A et al., menunjukkan bahwa vitamin B6 menghambat ekspresikan efek inflamasi, dimediasi oleh makrofag M2. ${ }^{28}$ Secara spesifik, vitamin B6 ditemukan dapat menurunkan IL6, yang menurunkan inflamasi secara signifikan. Hal ini telah terbukti penting untuk mengurangi ileus obstruksi pasca operasi..$^{27,28}$

Vitamin B6 dan turunannya PLP menghambat fosforilasi TLR-mediated TAK1, JNK, serta IKK-IKBa, yang menyebabkan penurunan aktivasi NF- $\mathrm{KB}$ and NLRP3-mediated caspase-1. Selain itu, PLP menekan ekspresi NLRP3dependent caspase-1 sehingga terjadi penurunan sekresi IL-1beta dan IL-18 dari makrofag. ${ }^{29}$ Jalur kanonikal yang diaktifkan NF-kB akan mengaktifkan caspase 1, menyebabkan berbagai respon stimulus patogenik seperti memicu apoptosis dan proses inflamasi lebih lanjut (peningkatan IL-1 $\beta$ dan IL-18). IL-1 $\beta$, yang terutama diproduksi oleh sel myeloid seperti monosit dan makrofag, menginduksi proliferasi dan/atau produksi sitokin inflamasi lainnya, seperti molekul adhesi leukosit, atau protein fase akut dalam leukosit, sel myeloid, sel endotel, hepatosit, dan lain sebagainya, dalam memicu proses inflamasi yang kuat. ${ }^{29}$

Vitamin B6 juga menghambat iNOS dan cyclooxygenase-2 (COX 2) yang diinduksi lipopolisakarida melalui penekanan aktivasi NF-kB, faktor transkripsi pro-inflamasi. Piridoksin ditemukan menekan ekspresi gen sitokin dalam makrofag dengan menghambat fosforilasi Toll-like receptor (TLR) yang dimediasi TAK1, yang menghambat jalur NF- $\kappa B$ dan JNK berikutnya. Hal ini menyebabkan penekanan produksi interleukin dan meningkatkan motilitas usus yang memiliki efek positif ke dalam prevensi adhesi intraperitoneal. ${ }^{25}$

\section{Efek Fibrinolisis}

Penelitian sebelumnya menemukan bahwa ada efek vitamin B6 pencegahan arteriosklerosis. Hal ini didasari pada penelitian pada hewan sebelumnya bahwa defisiensi vitamin B6 memicu arteriosklerosis. Pada penelitian mereka, mereka menemukan bahwa turunan vitamin B6, piridoksal fosfat secara signifikan memicu aktivitas fibrinolisis, tetapi pada dosis yang tinggi, baik secara in vivo maupun in vitro. ${ }^{30}$

\section{Efek Antioksidan}

Vitamin B6, meskipun tidak diklasifikasikan sebagai senyawa antioksidan klasik, baru-baru ini terbukti memiliki efek antioksidan yang sangat efisien. Piridoksin bertindak sebagai pemakan radikal hidroksil yang sangat efisien dengan kapasitas hingga delapan molekul OH. Penelitian menunjukkan bahwa vitamin B6 dapat mengurangi radikal superoksida dan kadar peroksida lipid yang diinduksi oleh $\mathrm{H} 2 \mathrm{O} 2$ dalam endotel vaskular. sel. Bukti yang muncul menunjukkan bahwa hidrogen sulfida (H2S) memberikan efek anti-oksidan dan anti-inflamasi yang kuat pada tingkat yang rendah. Studi terbaru menunjukkan bahwa suplementasi vitamin B6 menyebabkan peningkatan yang luar biasa dalam tingkat dipeptida imidazol, karnosin dan anserin, di jantung dan otot rangka tikus, mungkin dengan memodulasi enzim PLP untuk biosintesis. ${ }^{31}$ Carnosine memiliki berbagai manfaat kesehatan, termasuk antioksidan, anti-inflamasi, anti-glikasi, anti-iskemik, anti-kognitif, dann anti-penuaan. ${ }^{32}$

\section{SIMPULAN}

Vitamin B6 memiliki peranan dalam menghambat jalur inflamasi, fibrosis, dan oksidasi yang berkontribusi terhadap pembentukkan adhesi intraperitoneal. Vitamin B6 merupakan agen yang menjanjikan untuk digunakan sebagai prevensi adhesi intraperitoneal.

\section{KONFLIK KEPENTINGAN}

Tidak terdapat konflik kepentingan dalam penulisan tinjauan kepustakaan ini.

\section{ETIKA PENULISAN}

Tinjauan kepustakaan ini telah mengikuti pedoman etika publikasi berdasarkan pedoman COPE dan ICMJE.

\section{PENDANAAN}

Tidak ada.

\section{KONTRIBUSI PENULIS}

Seluruh penulis memiliki kontribusi yang sama dalam penulisan tinjauan kepustakaan ini baik dari penyusunan konsep dan desain, pencarian literatur, hingga interpretasi hasil dalam bentuk analisis dan sintesis tinjauan kepustakaan.

\section{DAFTAR PUSTAKA}

1. Brüggmann $\mathrm{D}$, Tchartchian $\mathrm{G}$, Wallwiener M, Münstedt K, Tinneberg HR, Hackethal A. Intra-abdominal adhesions: definition, origin, significance in surgical practice, and treatment options. Dtsch Arztebl Int. 2010;107(44):769775 .

2. Hellmann H, Mooney S. Vitamin B6: a molecule for human health?. Molecules. 2010;15(1):442459 .

3. Mooney S, Hellmann H. Vitamin B6: Killing two birds with one stone?. Phytochemistry. 2010;71(5-6):495-501.

4. Milingos S, Kallipolitis G, Loutradis D, et al. Adhesions: laparoscopic surgery versus laparotomy. Ann N Y Acad Sci. 2000;900:272285.

5. Diamond MP, Wexner SD, diZereg GS, Korell $\mathrm{M}$, Zmora O, Van Goor $\mathrm{H}$, et al. Adhesion prevention and reduction: current status and future recommendations of a multinational interdisciplinary consensus conference. Surg Innov. 2010;17(3):183-188.

6. Ergul E, Korukluoglu B. Peritoneal adhesions: facing the enemy. Int J Surg. 2008;6(3):253-260.

7. Ellis H, Moran BJ, Thompson JN, Parker MC, Wilson MS, Menzies D, et al. Adhesion-related hospital readmissions after abdominal and pelvic surgery: a retrospective cohort study. Lancet. 1999;353(9163):1476-1480. 
8. Atta HM. Prevention of peritoneal adhesions: a promising role for gene therapy. World $\mathrm{J}$ Gastroenterol. 2011;17(46):5049-5058.

9. Reed KL, Fruin AB, Bishop-Bartolomei KK, Gower AC, Nicolaou M, Stucchi AF, et al. Neurokinin-1 receptor and substance $\mathrm{P}$ messenger RNA levels increase during intraabdominal adhesion formation. J Surg Res. 2002;108(1):165-72.

10. Arung W, Meurisse M, Detry O. Pathophysiology and prevention of postoperative peritoneal adhesions. World J Gastroenterol. 2011;17(41):4545-4553.

11. Hoshino A, Kawamura YI, Yasuhara M, Toyama-Sorimachi N, Yamamoto K, Matsukawa A, et al. Inhibition of CCL1CCR8 interaction prevents aggregation of macrophages and development of peritoneal adhesions. J Immunol. 2007;178(8):5296-304.

12. Herrick SE, Mutsaers SE, Ozua P, Sulaiman $\mathrm{H}$, Omer A, Boulos P, et al. Human peritoneal adhesions are highly cellular, innervated, and vascularized. J Pathol. 2000;192(1):67-72.

13. Holmdahl $\mathrm{L}$, Ivarsson ML. The role of cytokines, coagulation, and fibrinolysis in peritoneal tissue repair. Eur J Surg. 1999;165(11):1012-1019.

14. Williams RS, Rossi AM, Chegini N, Schultz G. Effect of transforming growth factor beta on postoperative adhesion formation and intact peritoneum. J Surg Res. 1992;52(1):65-70.

15. Tafani M, Sansone L, Limana F, Arcangeli T, De Santis E, Polese M, et al. The Interplay of Reactive Oxygen Species, Hypoxia, Inflammation, and Sirtuins in Cancer Initiation and Progression. Oxid Med Cell Longev. 2016;2016:3907147.

16. Kondoh M, Ohga N, Akiyama K, Hida $\mathrm{Y}$, Maishi N, Towfik AM, et al. Hypoxia-induced reactive oxygen species cause chromosomal abnormalities in endothelial cells in the tumor microenvironment. PLoS One. 2013;8(11):e80349.

17. Tugasworo D, Kurnianto A, Retnaningsih, Andhitara Y, Ardhini R, Dyaksani R, et al. Recombinant tissue plasminogen activator (rTPA) in young adult patient with acute ischemic stroke: a case report. Bali Medical Journal. 2020;9(3):863-867.

18. Thakur M, Rambhatla A, Qadri F, Chatzicharalampous C, Awonuga M, Saed G, et al. Is There a Genetic Predisposition to Postoperative Adhesion Development? Reprod Sci. 2021;28(8):2076-2086.

19. Olczyk P, Mencner Ł, Komosinska-Vassev K. The role of the extracellular matrix components in cutaneous wound healing. Biomed Res Int. 2014;2014:747584.

20. Sulaiman H, Dawson L, Laurent GJ, Bellingan GJ, Herrick SE. Role of plasminogen activators in peritoneal adhesion formation. Biochem Soc Trans. 2002;30(2):126-131.

21. Rout UK, Diamond MP. Role of plasminogen activators during healing after uterine serosal lesioning in the rat. Fertil Steril. 2003;79(1):138145.

22. Tschumperlin DJ. Fibroblasts and the ground they walk on. Physiology (Bethesda). 2013;28(6):380-390.

23. Attard JA, MacLean AR. Adhesive small bowel obstruction: epidemiology, biology and prevention. Can J Surg. 2007;50(4):291-300.

24. Maciver AH, McCall M, James Shapiro AM. Intra-abdominal adhesions: cellular mechanisms and strategies for prevention. Int J Surg. 2011;9(8):589-594.
25. Ueland PM, McCann A, Midttun $\varnothing$, Ulvik A. Inflammation, vitamin B6 and related pathways. Mol Aspects Med. 2017;53:10-27.

26. ten Broek RP, Issa Y, van Santbrink EJ, Bouvy ND, Kruitwagen RF, Jeekel J, et al. Burden of adhesions in abdominal and pelvic surgery: systematic review and met-analysis. BMJ. 2013;347:f5588.

27. Víteček J, Lojek A, Valacchi G, Kubala L. Arginine-based inhibitors of nitric oxide synthase: therapeutic potential and challenges. Mediators Inflamm. 2012;2012:318087.

28. Ehmedah A, Nedeljkovic P, Dacic S, Repac J, Draskovic Pavlovic B, Vucevic D, et al. Vitamin B Complex Treatment Attenuates Local Inflammation after Peripheral Nerve Injury. Molecules. 2019;24(24):4615.

29. Zhang P, Tsuchiya K, Kinoshita T, Kushiyama H, Suidasari S, Hatakeyama M, et al. Vitamin B6 Prevents IL-1 $\beta$ Protein Production by Inhibiting NLRP3 Inflammasome Activation. J Biol Chem. 2016;291(47):24517-24527.

30. Vermaak WJ, Barnard HC, Potgieter GM, Theron HD. Vitamin B6 and coronary artery disease. Epidemiological observations and case studies. Atherosclerosis. 1987;63(2-3):235-238.

31. Corsello T, Komaravelli N, Casola A. Role of Hydrogen Sulfide in NRF2- and SirtuinDependent Maintenance of Cellular Redox Balance. Antioxidants (Basel). 2018;7(10):129.

32. Boldyrev AA, Aldini G, Derave W. Physiology and pathophysiology of carnosine. Physiol Rev. 2013;93(4):1803-1845. 